Volume IV, Nomor 3, DESEMBER 2021 : 159 - 168

JURNAL PERSEDA

https://jurnal.ummi.ac.id/index.php/perseda

\title{
Pengaruh Motivasi Orang Tua Terhadap Hasil Belajar Siswa pada Masa Pandemi
}

\author{
${ }^{1}$ Tiar Maylinda Nur Afifah, ${ }^{2}$ Oktian Fajar Nugroho \\ 1,2,( Pendidikan Guru Sekolah Dasar, FKIP, Universitas Esa Unggul Jakarta) \\ 1'tiarmaylindaaa@gmail.com, ${ }^{2}$ oktian.fajar@esaunggul.ac.id
}

\begin{abstract}
Abstrak
Penelitian ini bertujuan untuk mengetahui seberapa pengaruh Motivasi terhadap Hasil Belajar Siswa. Manfaat dari penelitian ini yaitu diharapkan memberikan perhatian lebih dalam membimbing dengan memberikan motivasi pada anak. Penelitian ini dilakukan di SDN Pasarkemis 2, kelas III B tahun ajaran 2020-2021. Metode dari Penelitian ini merupakan penelitian kuantitatif dengan menggunakan metode survey. Populasi dalam penelitian ini adalah siswa kelas III B yang berjumlah 38. Teknik pengumpulan data pada penelitian ini menggunakan angket. Hasil hipotesis dengan uji t Berdasarkan dari hasil data di atas dapat diketahui bahwa variabel motivasi memiliki nilai signifikan sebesar $0,000<$ dari tingkat signifikan 0.05, dengan nilai koefisien beta sebesar 0,788 memiliki arah pengaruh positif. Berdasarkan data tersebut, berarti variabel motivasi berpengaruh secara positif dan signifikan terhadap variabel hasil belajar.
\end{abstract}

Kata kunci: motivasi orang tua, hasil belajar

\section{PENDAHULUAN}

Saat ini karena kondisi yang memprihatinkan, sektor pendidikan mengalami kesulitan dalam belajar, sekolahan mulai dari SD, SMP bahkan SMA ditutup, dan sekolah diadakan di rumah alias belajar di rumah karena adanya pandemi yaitu virus yang mengharuskan untuk belajar di rumah, tetapi masih mendapatkan materi pembelajaran dari sekolah. Sebagai orang tua dan juga pendidik saat di rumah juga harus mengetahui sejauh mana anak paham dan sejauh mana materi yang telah dipelajari anak, di saat kondisi seperti ini perhatian dan motivasi orang tua pada anak sangat penting, apakah anak dapat mengingat materi nya dengan baik ataupun materi apa yang ia belum paham.

Disitu lah tugas orang tua memberi harus memperhatikan anaknya, dan tidak lupa memberikan motivasi, maka yang orang tua berikan dalam motivasi juga sangat diperlukan dalam membantu anak dalam belajar, agar anak lebih semangat juga dalam menjalankan kegiatannya, hasil belajar anak tinggi jika ditambah motivasi dari orang tua, karena dari motivasi orang tua anak akan lebih belajar dengan giat.
Penerbitan Undang-Undang (UU) Nomor 2 Tahun 2020 tentang Kebijakan Keuangan Negara dan Stabilitas Sistem Keuangan untuk Penanganan Pandemi Covid-19 dimaksudkan untuk memberikan perlindungan bagi kehidupan masyarakat yang sangat nyata terancam dengan merebak dan menyebarnya Covid-19, baik dari aspek keselamatan jiwa karena ancaman kesehatan dan keselamatan, maupun kehidupan sosial dan perekonomian masyarakat diungkapkan Menteri Keuangan (Menkeu) Sri Mulyani Indrawati.

WHO menemukan bahwa peternakan satwa liar di China menjadi asal usul virus corona penyebab pandemi Covid-19. Pandemi Covid-19 sudah berlangsung sejak awal 2020 dan sampai sekarang belum ada obatnya. Peternak satwa liar tersebut kemungkinan besar memasok hewan ke pedagang di Pasar Grosir Makanan Laut Huanan di Wuhan, tempat kasus pertama Covid-19 di temukan. Beberapa dari hewan liar yang dipasok bisa saja tertular SARS-CoV-2 dari kelelawar, virus corona beredar di kelelawar dan melompat ke manusia, kemungkinan melalui spesies perantara

Tujuan dari penelitian ini dilakukan untuk melihat seberapa pengaruh motivasi dari orang tua 
kepada anak dalam belajar, karena pada dasarnya masih banyak anak yang tugasnya masih belum dapat dilaksanakan dengan baik pada masa pandemi saat ini, sehingga diperlukan motivasi dari orang tua.

Menurut (Zahra, 2018) Motivasi merupakan dorongan orang tua kepada anak-anaknya, mendorong untuk meningkatkan semangat dan mengatasi masalah dalam proses pembelajaran selama pandemi. Motivasi dapat membantu mengembangkan cara yang lebih baik dalam mencapai tujuan, yaitu hasil belajar siswa yang maksimal. Anak tumbuh dan berkembang sesuai melalui pendidikan orang tua. Jika diinspirasi dari dalam, maka dapat membangkitkan motivasi untuk menggalakkan kegiatan belajar, memberikan bimbingan untuk pembelajaran di masa depan, dan membuat anak lebih semangat dalam belajar.

Semangat dan dorongan orang tua sangat penting untuk memotivasi dan menjalin kontak dengan anak, agar anak dapat semangat dalam kegiatan belajar. Setiap orang memiliki kemampuan yang berbeda, tergantung bagaimana anak tersebut menggunakan dan melatihnya. Kendala pendidikan saat ini adalah sulitnya siswa atau anak-anak memperoleh informasi yang telah dipelajari dalam memahami ataupun mengingat apa yang telah dipelajarinya, karena pembelajaran masih dilakukan secara jarak jauh. Guru berusaha menjelaskan melalui video, zoom meeting, whats app, youtube, atau media online lainnya

Menurut (Daryani, 2020) Orang tua ialah orang yang pertama kali bertanggung jawab kepada anakanaknya, yaitu bertanggungjawab secara material, spiritual dan psikologis. Orang tua adalah pembina pribadi yang pertama dalam hidup anak.

Menurut (Dwijayani, 2019) hasil belajar merupakan ketika seseorang telah belajar dan tingkah lakunya berubah. Nana Sudjana menyampaikan bahwa hasil belajar merupakan salah satu bentuk keahlian yang didapat anak sesudah melakukan kegiatan belajarr yang dilaksanakan. Hasil belajar merupakan hasil pencapaian yang pertama kali dialami seseorang dalam proses pembelajaran. Dari proses pembelajaran terakhir akan selalu ada nilai akhirr, dan nilai akhir menjadi puncak pencapaian kemampuan dan kualitas siswa dalam proses pembelajaran.

\section{METODE}

Metode Penelitian

Penelitian ini memakai pendekatan kuantitatif. Penelitian dibuat mengguanakan metode kuesioner yaitu menggunakan kuesioner menggunakan sampel populasi sebagai alat pengumpulan data. Teknik penelitian memakai korelasional yaitu buat melihat interaksi antara variabel satu menggunakan yang lain (Saputra et al., 2018).

Populasi, Sampel, dan Teknik Pengambilan Sampel

\section{Populasi Penelitian}

Populasi pada penelitian ini ialah siswa SDN Pasarkemis 2.

\section{Sampel Penelitian}

Sampel yang terdapat di penelitian berikut ialah anak kelas 3 B yang berjumlah 34 siswa. Indikator motivasi orang tua sebagai berikut:

1. Menanyakan hasil belajar anak dengan memahami hasil belajar anak.

2. Puji-pujian yaitu para orang tua mendorong anaknya untuk lebih giat belajar.

3. Orang tua memberi apresiasi untuk anak supaya lebih semangat dalam belajar lebih giat.

4. Memberi sanksi kepada anak untuk mencegah mereka melakukan kesalahan yang sama lagi.

Definisi Oprasional

1. Motivasi Orang Tua

Skor yang diperoleh dari hasil mengisi lembar angket mengenai motivasi orang tua dengan tahapan: a) Menanyakan hasil belajar anak dengan memahami hasil belajar anak. b) Pujipujian yaitu para orang tua mendorong anaknya untuk lebih giat belajar. c) Orang tua memberi apresiasi untuk anak supaya lebih semangat dalam belajar lebih giat. d) Memberi sanksi kepada anak untuk mencegah mereka melakukan kesalahan yang sama lagi.

2. Hasil Belajar

Penguasaan bahan pelajaran dengan nilai akhir yang dimiliki siswa setelah meneriman pengalaman belajar dan motivasi dari orang tua dimasa pandemi.

Teknik Pengumpulan Data

Untuk mendapatkan data yang diminta, peneliti memakai sarana teknis sebagai berikut:

\begin{tabular}{|c|c|c|}
\hline No & Keterangan & Instrumen \\
\hline 1. & $\begin{array}{c}\text { Motivasi } \\
\text { Orang Tua }\end{array}$ & Kuesioner \\
\hline 2. & Hasil Belajar & Survey \\
\hline
\end{tabular}


Instrumen

Langkah-langkah mempersiapkan alat penelitian:

1. Motivasi orang tua pada penelitian ini merupakan dorongan yang diberikan oleh orang tua untuk anak untuk membangkitkan semangat dan mengatasi masalah saat sedang belajar, dengan adanya motivasi dapat membantu ke arah yang lebih baik dalam mencapai tujuannya.

Kisi-kisi Lembar Angket/Kuesioner

Lembar Angket Motivasi Positif

\begin{tabular}{|c|c|c|c|c|}
\hline Variabel & Sub Variabel & Indikator & $\begin{array}{c}\text { No } \\
\text { Item }\end{array}$ & Jml \\
\hline \multirow{4}{*}{$\begin{array}{c}\text { Motivasi } \\
\text { Orang } \\
\text { Tua }\end{array}$} & $\begin{array}{c}\text { Mengetahui } \\
\text { Hasil }\end{array}$ & $\begin{array}{c}\text { Menanyakan } \\
\text { hasil belajar } \\
\text { anaknya dengan } \\
\text { mengetahui } \\
\text { hasil belajar } \\
\text { yang didapat } \\
\text { oleh anaknya. }\end{array}$ & $\begin{array}{l}1,2 \\
3,4\end{array}$ & 4 \\
\hline & Pujian & $\begin{array}{c}\text { Orang tua untuk } \\
\text { memberi kata } \\
\text { kata motivasi } \\
\text { untuk anak } \\
\text { supaya lebih } \\
\text { semangat dalam } \\
\text { belajar lebih } \\
\text { giat. }\end{array}$ & $\begin{array}{c}5,6 \\
7,8\end{array}$ & 4 \\
\hline & Hadiah & $\begin{array}{c}\text { Memberikan } \\
\text { sebuah apresiasi } \\
\text { atas nilai } \\
\text { pelajarannya } \\
\text { pada ulangan } \\
\text { yang tinggi } \\
\text { supaya lebih } \\
\text { giat dalam } \\
\text { belajar }\end{array}$ & 9,10 & 2 \\
\hline & Hukuman & $\begin{array}{c}\text { Pemberian } \\
\text { sangsi kepada } \\
\text { anak supaya } \\
\text { tidak } \\
\text { mengulangi } \\
\text { kesalahan yang } \\
\text { sama apa yang } \\
\text { telah } \\
\text { dilakukannya. }\end{array}$ & $\begin{array}{l}11, \\
12, \\
13, \\
14, \\
15\end{array}$ & 5 \\
\hline \multicolumn{4}{|c|}{ Jumlah } & 15 \\
\hline
\end{tabular}

Lembar Angket Motivasi Negatif

\begin{tabular}{|c|c|c|c|c|}
\hline Variabel & Sub Variabel & Indikator & $\begin{array}{c}\text { No } \\
\text { Item }\end{array}$ & Jumlah \\
\hline \multirow{2}{*}{$\begin{array}{c}\text { Motivasi } \\
\text { Orang } \\
\text { Tua }\end{array}$} & $\begin{array}{c}\text { Mengetahui } \\
\text { Hasil }\end{array}$ & $\begin{array}{c}\text { Menanyakan } \\
\text { hasil belajar } \\
\text { anaknya } \\
\text { dengan } \\
\text { mengetahui } \\
\text { hasil belajar } \\
\text { yang didapat } \\
\text { oleh anaknya. }\end{array}$ & $\begin{array}{l}1,2 \\
3,4\end{array}$ & 4 \\
\hline & Pujian & $\begin{array}{c}\text { Orang tua } \\
\text { untuk } \\
\text { memberi kata } \\
\text { kata motivasi } \\
\text { untuk anak } \\
\text { supaya lebih } \\
\text { semangat } \\
\text { dalam belajar } \\
\text { lebih giat. }\end{array}$ & 5,6 & 2 \\
\hline
\end{tabular}

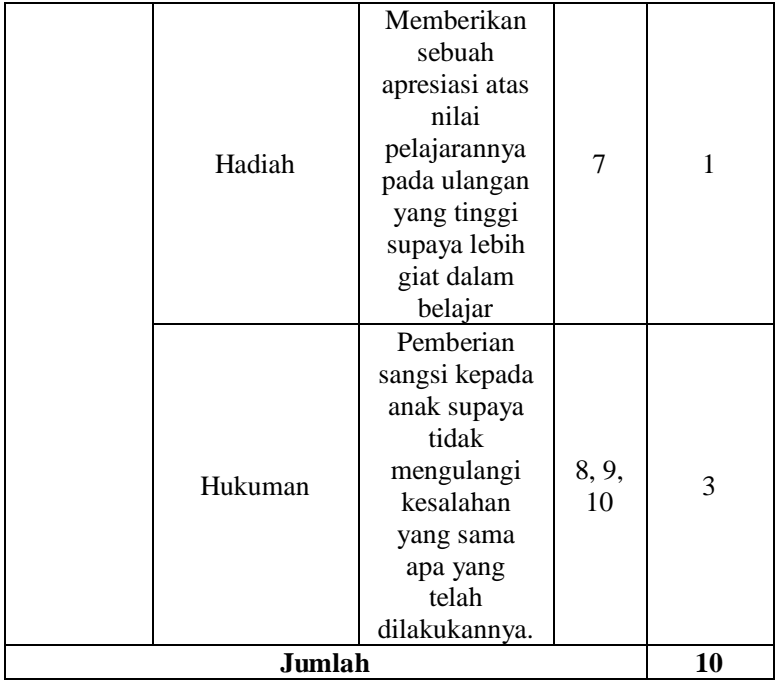

2. Hasil belajar, pengertian hasil belajar ialah keterampilan anak dapat dilihat melalui hasil belajar siswa peroleh. Seperti ranah kognitif yang menilai kemampuan berpikir anak dari teori Bloom.

Teknik Analisis Data

1. Uji Validitas Instrumen

Validitas dianggap sebagai syarat penting di suatu alat evaluasi. Suatu tes dikatakan valid jika tes tersebut bisa diukur buat mengukur yang seharusnya diukur. Dikatakan valid jika $r$ hitung > r tabel di taraf signifikan 0,05.

Indikator pertanyaan bakal dinyatakan valid asal tampilan output IBM SPSS 24.0 ditampilkan. Statistik ditabel korelasi total item yang benar menggunakan nilai korelasi. Uji validitas pada penelitian ini melibatkan 34 responden yang menjadi sampel penelitian. Berikut ini adalah hasil uji validitas untuk pernyataan item variabel motivasi orang tua menjadi berikut.

Uji validitas dalam penelitian ini menggunakan penilaian pakar (obtain judgement expert)

$\mathrm{P}(\mathrm{s})=\frac{s}{n} \times 100 \%$

Ket:

$\mathrm{P}(\mathrm{s})$ : Nilai setiap butir pernyataan

$\mathrm{s}$ : Skor setiap butir penyataan

$\mathrm{N}$ : Jumlah keseluruhan butir pernyataan

2. Uji Reliabilitas

Pengukuran reliabilitas dikerjakan dengan memakai uji statistik Cronbach Alpha. Di ilmu statistik, Cronbach Alpha ialah koefisien berdasarkan konsistensi internal yang umumnya dipakai buat menguji reliabilitas. 
Indikator pertanyaan diucapkan reliabel apabila nilai cronbach alpha $>0,60$. Hasil uji reliabilitas berikut disajikan pada tabel dibawah ini.

Uji realibilitas dalam penelitian ini menggunakan rumus Alfa Cronbach

$$
\alpha=\frac{n}{n-1}\left(1-\frac{\Sigma_{i} V_{i}}{V_{t}}\right)
$$

Ket:

a: Koefisien alfa

n: Jumlah butir pernyataan

Vi: Simpangan baku setiap butir pernyataan

Vt: Simpangan baku keseluruhan

Tabel 1

Hasil Uji Reliabilitas Variabel Motivasi

\begin{tabular}{|c|c|c|c|c|}
\hline Variabel & $\begin{array}{c}\text { n } \\
\text { item }\end{array}$ & $\begin{array}{c}\text { Cronbach's } \\
\text { Alpha }\end{array}$ & Alpha & Keterangan \\
\hline $\begin{array}{c}\text { Motivasi } \\
\text { Orang } \\
\text { Tua }\end{array}$ & 25 & 0,936 & 0,600 & Reliabel \\
\hline
\end{tabular}

Sumber: Data Olahan Peneliti, 2021

Hasil uji reliabilitas memberitahukan pada penelitian ini variabel motivasi orang tua yang dipakai mempunyai nilai Cronbach's Alpha-nya lebih besar dari 0,60. Bisa dimaknai sedemikian rupa sehingga alat penelitian ini bisa secara konsisten menghasilkan langkah-langkah konseptual dan bias yang terjadi bisa diminimalisir. Instrumen yang dipakai pada penelitian ini konsisten sebagai alat ukur.

\section{Analisis Deskriptif}

Langkah yang digunakan dalam angket dengan jawaban alternatif dengan memberi nilai pada setiap item jawaban dengan kriteria sebagai berikut:

Angket Positif

a. Untuk alternatif jawaban SS dengan skor 4 .

b. Untuk alternatif jawaban S dengan skor 3 .

c. Untuk alternatif jawaban TS dengan skor 2 .

d. Untuk alternatif jawaban STS dengan skor 1. Angket Negatif

a. Untuk alternatif jawaban SS dengan skor 1 .

b. Untuk alternatif jawaban S dengan skor 2 .

c. Untuk alternatif jawaban TS dengan skor 3.

d. Untuk alternatif jawaban STS dengan skor 4.

Sesudah data terkumpul, peneliti mengevaluasi data motivasi orang tua sesuai standar skor yang sudah ditetapkan lalu disusun pada angket motivasi orang tua. Sementara data hasil belajar, peneliti mengambil hasil tes ujian tulis murid kelas 3 SD Pasarkemis 2 kabupaten Tangerang yang sebagai responden dalam semester genap tahun ajaran 2020/2021. Selain itu, setiap masing data (yang memberikan motivasi orang tua dan hasil belajar siswa kelas 3 SD Pasarkemis 2) disajikan sebagai table distribusi nilai skor. Dari table distribusi skor Mean (rata-rata), anda dapat melihat rata-rata untuk setiap variabel (variabel $\mathrm{X}$ motivasi orang tua dan variabel Y: hasil belajar). Menurut table kecendrungan variabel dilakukan buat dikategorikan berdasarkan skor atau nilai yang diperoleh dari setiap variabel memakai mean dan standar deviasi ideal.

\section{HASIL DAN PEMBAHASAN}

Penelitian ini merupakan penelitian kuantitatif. Penelitian ini terdiri dari dua variabel yaitu, variabel motivasi (X) dan variabel hasil belajar (Y). Data penelitian motivasi dan hasil belajar didapat dari hasil kuesioner yang terkumpul dari 34 siswa. Untuk mendapatkan data penelitian, peneliti menggunakan angket atau kuesioner sebagai instrumen variabel motivasi dengan penetapan skor memakai Skala Likert yg terdiri menurut empat cara lain jawaban sangat setuju (SS), setuju (S), tidak setuju (TS), dan sangat tidak setuju (STS).

Skala Likert merupakan skala yang menunjukkan jarak antara satu data dengan data yang lain dan mempunyai bobot yang sama dan pengukuran yang biasa digunakan untuk menyatakan peringkat untuk antar tingkatan. Sedangkan untuk instrumen hasil belajar peneliti menggunakan survey hasil nilai belajar. Angket atau kuesioner penelitian disebarkan kepada sampel penelitian yaitu siswa kelas 3 B Tahun Pelajaran 2020/2021 SDN Pasarkemis 2. Deskripsi data juga menyajikan hasil frekuensi kategori variabel, untuk mengetahui deskripsi masing-masing variabel secara rinci dapat dilihat sebagai berikut.

Instrumen yang digunakan dalam mengumpulkan data adalah kuesioner untuk variabel motivasi, dan untuk hasil belajar dengan survey hasil nilai belajar. Sebelum melakukan analisi untu uji hipotesis penelitian, angket atau kuesioner di uji instrumen terlebih dahulu yaitu uji validitas dan reliabilitas. Hasil uji validitas pada kuesioner motivasi diperoleh 25 butir pernyataan semua valid, yang terdiri dari motivasi positif sebanyak 15 butir dan motivasi negatif sebanyak 10 
butir pernyataan. Nilai uji validitas motivasi mulai dari 0,412 sampai 0,762.

Hasil pada uji reliabilitas membagikan bahwa variabel motivasi orang tua yang dipergunakan pada penelitian ini mempunyai nilai Cronbach's Alphanya lebih besar dari 0,60. Dapat diartikan maka instrumen ini bisa membentuk ukuran konsep yang konsisten dan bias yang terjadi bisa diminimalkan.

Pada hasil uji deskriptif variabel hasil belajar dapat diketahui perolehan nilai minimum sebesar 72,00, maksimum sebesar 85,00, mean sebesar 78,59 , median sebesar 78,00, modus sebesar 76,00, standar deviasi sebesar 3,29. Hasil distribusi frekuensi kecenderungan atau kategori variabel hasil belajar menunjukkan bahwa sebagian besar siswa memiliki nilai hasil belajar dalam kategori sedang sebanyak $44,1 \%$, dan paling sedikit dalam kategori rendah sebanyak $11,8 \%$. Hasil nilai rata-rata atau mean sebesar 78,59 termasuk dalam kategori sedang.

Variabel motivasi bisa ditemukan perolehan nilai minimum sebesar 62,00, maksimum sebesar 96,00, mean sebesar 75,85, median sebesar 74,00, modus sebesar 74,00, standar deviasi sebesar 9,40. Hasil distribusi frekuensi kecenderungan atau kategori variabel motivasi menentukan bahwa setengah besar murid mempunyai nilai motivasi padan kategori tinggi sebanyak $44,1 \%$, dan paling sedikit dalam kategori sedang sebanyak $26,5 \%$. Hal ini sesuai dengan hasil nilai rata-rata atau mean sebesar 75,85 termasuk dalam kategori tinggi.

Analisis selanjutnya uji prasyarat yang terdiri dari uji normalitas dan uji linieritas. Hasil perhitungan uji normalitas menggunakan Lilliefors dalam tabel one-sample kolmogorov-smirnov test nilai signifikansi adalah 0,200 lebih besar dari 0,05, sebagai akibatnya data model regresi berdistribusi normal. Hasil uji linieritas dicermati berdasarkan nilai signifikansi pada Deviation From Linearity $0,160>0,05$ sehingga kedua variabel bekerjasama secara linear.

Langkah selanjutnya melakukan uji regresi linear uji regresi linear sederhana. Uji regresi linear sederhana menggunakan program SPSS for windows release 24. Diketahui nilai pada linear sederhana pada $\mathrm{X}$ dan $\mathrm{Y}$ adalah konstanta $(\alpha)$ sebesar 57,718 dan nilai (b) atau koefisien regresi sebesar 0,275 , sehingga persamaan regresinya adalah $\widehat{Y}=57,718+0,275 X$. Nilai korelasi antara variabel motivasi (X) dengan hasil belajar (Y) sebesar 0,788. Angka tadi berada antara 0,60 0,799 , sehingga bisa disimpulkan bahwa adanya korelasi yang kuat antara variabel motivasi (X) dengan hasil belajar (Y).

Tahap selanjutnya melakukan uji hipotesis memakai uji kolerasi (r), uji determinasi $\left(\mathrm{R}^{2}\right)$, uji parsial (t) serta uji simultan (F). Uji kolerasi (r) dengan menggunakan SPSS for windows release 24 dapat diketahui nilai koefisien kolerasi antara $\mathrm{X}$ dengan $\mathrm{Y}$ sebesar 0,788 menggunakan nilai signifikansi $0,000<0,05$, yang artinya ada kolerasi antara X dan Y. Kedua variabel berkorelasi secara signifikan dan memiliki arah positif. Bila motivasi semakin tinggi maka hasil belajar pula semakin meningkat, dan begitu juga sebaliknya.

Kemudian dilakukannya uji determinasi $\left(\mathrm{R}^{2}\right)$ menggunakan progam SPSS for windows release 24 , dapat diketahui nilai $R$ Square adalah 0,620 , hal ini berarti $62,0 \%$ variasi variabel terikat yaitu hasil belajar bisa dijelaskan dengan variasi variabel bebas yaitu motivasi. Sedangkan sisanya sebanyak 38,0\% variabel dependen hasil belajar dijelaskan dengan variabel lain yang tidak dijelaskan pada penelitian ini. Adapun hasil perhitungan uji parsial (t) bisa diketahui bahwa variabel motivasi memiliki nilai signifikan sebesar $0,000<$ dari tingkat signifikan 0.05 , oleh nilai koefisien beta sebesar 0,788 memiliki arah pengaruh positif, artinya motivasi mempunyai pengaruh positif dan signifikan terhadap hasil belajar, semakin tinggi motivasi bahwa semakin tinggi pula hasil belajar siswa.

Hasil uji simultan $(\mathrm{F})$ diperoleh perhitungan nilai $\mathrm{F}_{\text {tabel }}$ sebesar 4,17 dengan nilai $\mathrm{F}_{\text {hitung }}=$ $52,247>\mathrm{F}_{\text {tabel }}=4,17$ dengan signifikansi $0,000<$ 0,05 . Hasil ini memperlihatkan $F_{\text {hitung }}$ signifikan, sebagai akibatnya Ho ditolak dan $\mathrm{Ha}$ diterima. Berdasarkan hasil tersebut, maka terdapat pengaruh positif dan signifikan motivasi secara simultan terhadap hasil belajar siswa.

1. Motavasi Orang Tua (X)

Jumlah pernyataan kuesioner motivasi terdiri dari 25 butir yang terdiri dari motivasi positif sebanyak 15 butir dan motivasi negatif sebanyak 10 butir pernyataan dengan empat alternatif jawaban STS, TS, S, SS, skor yang diberikan adalah 1, 2, 3, dan 4 untuk motivasi positif, sedangkan empat alternatif jawaban STS, TS, S, SS, skor yang diberikan adalah 4, 3, 2, dan 1 untuk motivasi positif. Data yang diperoleh kemudian

dianalisis menggunakan bantuan program SPSS for windows realese 24. Hasil perhitungan deskriptif statistik variabel motivasi dapat dilihat pada tabel sebagai berikut. Hasil perhitungan deskriptif 
selanjutnya mencari nilai frekuensi kategori variabel motivasi

Tabel 2. Hasil deskriptif Statistik Variabel Motivasi

\begin{tabular}{|c|c|c|}
\hline \multicolumn{3}{|c|}{ Statistics } \\
\hline \multicolumn{3}{|c|}{ Motivasi } \\
\hline \multirow[t]{2}{*}{$\mathrm{N}$} & Valid & 34 \\
\hline & Missing & 0 \\
\hline \multicolumn{2}{|c|}{ Mean } & 75,8529 \\
\hline \multicolumn{2}{|c|}{ Median } & 74,0000 \\
\hline \multicolumn{2}{|c|}{ Mode } & $74,00^{\mathrm{a}}$ \\
\hline \multicolumn{2}{|c|}{ Std. Deviation } & 9,40384 \\
\hline \multicolumn{2}{|c|}{ Minimum } & 62,00 \\
\hline \multicolumn{2}{|c|}{ Maximum } & 96,00 \\
\hline \multicolumn{2}{|c|}{ Sum } & 2579,00 \\
\hline
\end{tabular}

yang akan diinterpretasikan ke dalam bentuk distribusi frekuensi dan persentase. Langkahlangkah untuk menentukan banyak kategori adalah dengan perhitungan sebagai berikut.

Skor tertinggi ideal $=4 \times 25=100$

Skor terendah ideal $=1 \times 25=25$

Mean ideal

$=1 / 2($ skor tertinggi - skor terendah $)$

$=1 / 2(100,00+25,00)$

$=1 / 2(125,00)$

$=62,50$

Standar deviasi ideal

$=1 / 6($ skor tertinggi - skor terendah $)$

$=1 / 6(100,00-25,00)$

$=1 / 6(75,00)$

$=12,50$

Perhitungan rumus kecendrungan atau kategori variabel dilakukan untuk mengkategorikan berdasarkan nilai yang diperoleh dari setiap variabel dengan menggunakan mean dan standar deviasi ideal berikut.

\begin{tabular}{|c|c|c|c|}
\hline Rendah & $=X \leq N$ & $-1.5 \mathrm{SD}$ & \\
\hline $\begin{array}{l}\text { Sedang } \\
\text { SD }\end{array}$ & $=\mathrm{M}-1$ & $5 \mathrm{SD}<\mathrm{X}$ & $M+0.5$ \\
\hline $\begin{array}{l}\text { Tinggi } \\
\text { SD }\end{array}$ & $=M+c$ & $5 \mathrm{SD}<\mathrm{X}$ & $M+1.5$ \\
\hline Sangat Ting & $=X>N$ & $+1.5 \mathrm{SD}$ & \\
\hline Distribusi & rekuensi & Kategori & Iotivasi \\
\hline $\begin{array}{c}\text { Batas } \\
\text { Interval }\end{array}$ & Frekuensi & $\begin{array}{c}\text { Frekuensi } \\
\text { Relatif } \\
(\%)\end{array}$ & $\begin{array}{c}\text { Frekuensi } \\
\text { Kumulatif } \\
(\%)\end{array}$ \\
\hline $\begin{array}{c}25,00- \\
43,75 \\
\end{array}$ & 0 & 0,0 & 0,0 \\
\hline $\begin{array}{l}43,76- \\
68,75\end{array}$ & 9 & 26,5 & 26,5 \\
\hline
\end{tabular}

\begin{tabular}{|c|c|c|c|c|}
\hline Tinggi & $\begin{array}{c}68,76- \\
81,25\end{array}$ & 15 & 44,1 & 70,6 \\
\hline $\begin{array}{c}\text { Sangat } \\
\text { Tinggi }\end{array}$ & $\begin{array}{c}81,26- \\
100,0\end{array}$ & 10 & 29,4 & 100,0 \\
\hline Total & & $\mathbf{3 4}$ & $\mathbf{1 0 0}$ & \\
\hline
\end{tabular}

Sumber: Data Olahan Peneliti, 2021

Hasil distribusi frekuensi kecenderungan atau kategori variabel motivasi menunjukkan bahwa sebagian besar siswa memiliki nilai motivasi dalam kategori tinggi sebanyak $44,1 \%$, dan paling sedikit dalam kategori sedang sebanyak 26,5\%. Hal ini sesuai dengan hasil nilai rata-rata atau mean sebesar 75,85 termasuk dalam kategori tinggi.

2. Hasil belajar (Y)

Analisis deskriptif hasil belajar siswa dilakukan dengan statistik deskriptif, yaitu mendiskripsikan data yang telah diperoleh dengan nilai minimum, maksimum, median, modus, mean dan standar deviasi. Data yang diperoleh kemudian dianalisis menggunakan bantuan program SPSS for windows realese 24. Hasil perhitungan statistik variabel hasil belajar dapat dilihat pada tabel sebagai berikut.

Tabel 4 Hasil Deskriptif Statistik Variabel Hasil belajar

\begin{tabular}{|c|c|c|}
\hline \multicolumn{3}{|l|}{ Statistics } \\
\hline \multicolumn{3}{|l|}{ Hasil Belajar } \\
\hline \multirow[t]{2}{*}{$\mathrm{N}$} & Valid & 34 \\
\hline & Missing & 0 \\
\hline Mean & & 78,5882 \\
\hline Median & & 78,00 \\
\hline Mode & & 76,00 \\
\hline Std. Deviation & & 3,28558 \\
\hline Minimum & & \begin{tabular}{|l|}
72,00 \\
\end{tabular} \\
\hline Maximum & & 85,00 \\
\hline Sum & & 2672,00 \\
\hline
\end{tabular}

Sumber: Data Olahan Peneliti, 2021

A. Uji Hipotesis

1. Uji Analisis Regresi Linear Sederhana

Tabel 8. Hasil Uji Regresi Liniear Sederhana

\begin{tabular}{|c|c|c|c|c|c|}
\hline \multicolumn{6}{|l|}{ Coefficients $^{a}$} \\
\hline \multirow[b]{2}{*}{ Model } & \multicolumn{2}{|c|}{$\begin{array}{l}\text { Unstandardized } \\
\text { Coefficients }\end{array}$} & \multirow{2}{*}{$\begin{array}{l}\text { Standardized } \\
\text { Coefficients } \\
\text { Beta }\end{array}$} & \multirow[b]{2}{*}{$t$} & \multirow[b]{2}{*}{ Sig. } \\
\hline & $\mathrm{B}$ & $\begin{array}{l}\text { Std. } \\
\text { Error }\end{array}$ & & & \\
\hline $1 \quad$ (Constant & 57,718 & 2,909 & & 19,842 &, 000 \\
\hline Motivasi & ,275 & ,038 & ,788 & 7,228 &, 000 \\
\hline
\end{tabular}

Sumber: Data Olahan Peneliti, 2021 
2. Uji Analisis Koefisien Determinasi

Tabel 9. Hasil uji koefisien determinasi

\begin{tabular}{|c|c|c|c|c|}
\hline \multicolumn{5}{|c|}{ Model Summaryb } \\
\hline $\begin{array}{l}\text { Mod } \\
\text { el }\end{array}$ & $\mathrm{R}$ & $\begin{array}{l}\mathrm{R} \\
\text { Squar } \\
\mathrm{e}\end{array}$ & $\begin{array}{ll}\text { Adjusted } & R \\
\text { Square } & \end{array}$ & $\begin{array}{l}\text { Std. } \\
\text { Error of } \\
\text { the } \\
\text { Estimate }\end{array}$ \\
\hline$\overline{1}$ & ,788 & ,620 & ,608 & 2,05633 \\
\hline
\end{tabular}

a. Predictors: (Constant), Motivasi

b. Dependent Variable: Hasil Belajar

Sumber: Data Olahan Peneliti, 2021

3. Uji Hipotesis (Uji t)

Tabel 10. Hasil Uji Hipotesis (Uji t)

\begin{tabular}{|c|c|c|c|c|c|}
\hline \multicolumn{6}{|c|}{ Coefficients $^{\mathbf{a}}$} \\
\hline \multirow[b]{2}{*}{ Model } & \multicolumn{2}{|c|}{$\begin{array}{l}\text { Unstandardi } \\
\text { zed } \\
\text { Coefficients }\end{array}$} & \multirow{2}{*}{$\begin{array}{l}\text { Standardiz } \\
\text { ed } \\
\text { Coefficien } \\
\text { ts } \\
\text { Beta }\end{array}$} & \multirow[b]{2}{*}{$\mathrm{t}$} & \multirow[b]{2}{*}{$\begin{array}{l}\text { Sig } \\
\text {. }\end{array}$} \\
\hline & $\mathrm{B}$ & $\begin{array}{l}\text { Std. } \\
\text { Error }\end{array}$ & & & \\
\hline $\begin{array}{l}1 \text { (Consta } \\
\text { nt) }\end{array}$ & $\begin{array}{l}57,7 \\
18\end{array}$ & 2,909 & & $\begin{array}{l}19,8 \\
42\end{array}$ & $\begin{array}{l}, 00 \\
0\end{array}$ \\
\hline $\begin{array}{l}\text { Motivas } \\
\mathrm{i}\end{array}$ & 275 &, 038 & ,788 & \begin{tabular}{|l|}
7,22 \\
8 \\
\end{tabular} & $\begin{array}{l}\text {,00 } \\
\mathbf{0}\end{array}$ \\
\hline
\end{tabular}

a. Dependent Variable: Hasil Belajar

Sumber: Data Olahan Peneliti, 2021

Berdasarkan hasil tabel hasil deskriptif variabel hasil belajar di atas, dapat diketahui perolehan nilai minimum sebesar 72,00, maksimum sebesar 85,00, mean sebesar 78,59, median sebesar 78,00 , modus sebesar 76,00, standar deviasi sebesar 3,29 . Hasil perhitungan deskriptif hasil belajar kemudian diinterpretasikan ke dalam bentuk distribusi frekuensi kategori.

Hasil perhitungan deskriptif selanjutnya mencari nilai frekuensi kategori variabel hasil belajar yang akan diinterpretasikan ke dalam bentuk distribusi frekuensi dan persentase. Langkahlangkah untuk menentukan banyak kategori adalah dengan perhitungan sebagai berikut.

Skor tertinggi (maximum) $\quad=85,00$

Skor terndah (minimum) $\quad=72,00$

Mean ideal $=1 / 2$ (skor tertinggi - skor terendah)

$$
\begin{aligned}
& =1 / 2(85,00+75,00) \\
& =1 / 2(157,00) \\
& =78,50
\end{aligned}
$$

Standar deviasi ideal $=1 / 6$ (skor tertinggi - skor terendah)

$$
\begin{aligned}
& =1 / 6(85,00-75,00) \\
& =1 / 6(13,00) \\
& =2,20
\end{aligned}
$$

Perhitungan rumus kecendrungan atau kategori variabel dilakukan untuk mengkategorikan berdasarkan skor atau nilai yang diperoleh dari

\begin{tabular}{|c|c|c|c|c|}
\hline Kategori & $\begin{array}{c}\text { Batas } \\
\text { Interval }\end{array}$ & Frek & $\begin{array}{c}\text { Frekuensi } \\
\text { Relatif } \\
(\%)\end{array}$ & $\begin{array}{c}\text { Frekuensi } \\
\text { Kumulatif } \\
(\%)\end{array}$ \\
\hline Rendah & $\begin{array}{l}72,00- \\
75,25\end{array}$ & 4 & 11,8 & 11,8 \\
\hline Sedang & $\begin{array}{c}75,26- \\
79,58\end{array}$ & 15 & 44,1 & 55,9 \\
\hline Tinggi & $\begin{array}{l}79,59- \\
81,75\end{array}$ & 7 & 20,6 & 76,5 \\
\hline $\begin{array}{l}\text { Sangat } \\
\text { Tinggi }\end{array}$ & $\begin{array}{l}81,76- \\
85,00\end{array}$ & 8 & 23,5 & 100,0 \\
\hline Total & & 34 & 100 & \\
\hline
\end{tabular}
setiap variabel dengan menggunakan mean dan standar deviasi ideal berikut.

$$
\begin{array}{lr}
\begin{array}{l}
\text { Rendah } \\
\text { Sedang }
\end{array} & =\mathrm{X} \leq \mathrm{M}-1.5 \mathrm{SD} \\
\begin{array}{l}
\text { Tinggi } \\
\text { SD }
\end{array} & =\mathrm{M}+0.5 \mathrm{SD}<\mathrm{X} \leq \mathrm{M}+1.5 \\
& \\
\text { Sangat Tinggi } & =\mathrm{X}>\mathrm{M}+1.5 \mathrm{SD}
\end{array}
$$

Tabel 5 Distribusi Frekuensi Kategori Hasil belajar

Sumber: Data Olahan Peneliti, 2021

Hasil distribusi frekuensi kecenderungan atau kategori variabel hasil belajar menunjukkan bahwa sebagian besar siswa memiliki nilai hasil belajar dalam kategori sedang sebanyak $44,1 \%$, dan paling sedikit dalam kategori rendah sebanyak 11,8\%. Hal ini sesuai dengan hasil nilai rata-rata atau mean sebesar 78,59 termasuk dalam kategori sedang.

C. Uji Prasyarat

1. Uji Normalitas

Tabel 6. Hasil Uji Normalitas

One-Sample Kolmogorov-Smirnov Test Unstandardized Residual

\begin{tabular}{lll}
\hline $\mathrm{N}$ & \multicolumn{2}{c}{34} \\
\hline $\begin{array}{l}\text { Normal } \\
\text { Parameters }\end{array}$ & Mean &, 0000000 \\
& & Std. \\
& Deviation & 2,02493064 \\
\hline & Absolute &, 112
\end{tabular}




\begin{tabular}{|c|c|c|}
\hline \multirow{2}{*}{$\begin{array}{l}\text { Most Extreme } \\
\text { Differences }\end{array}$} & Positive & 056 \\
\hline & Negative &,- 112 \\
\hline \multicolumn{2}{|l|}{ Test Statistic } & 112 \\
\hline \multicolumn{2}{|c|}{ Asymp. Sig. (2-tailed) } & ,200 \\
\hline \multicolumn{3}{|c|}{ a. Test distribution is Normal. } \\
\hline \multicolumn{3}{|c|}{ b. Calculated from data. } \\
\hline \multicolumn{3}{|c|}{ c. Lilliefors Significance Correction. } \\
\hline \multicolumn{3}{|c|}{ d. This is a lower bound of the true significance. } \\
\hline
\end{tabular}

Sumber: Data Olahan Peneliti, 2021.

2. Uji Linearitas

Tabel 7. Hasil Uji Linearitas

\begin{tabular}{|c|c|c|c|c|c|c|}
\hline \multicolumn{7}{|c|}{ ANOVA Table } \\
\hline & & $\begin{array}{l}\text { Sum of } \\
\text { Square } \\
\text { s }\end{array}$ & df & $\begin{array}{l}\text { Mean } \\
\text { Square }\end{array}$ & $\mathrm{F}$ & Sig. \\
\hline \multirow{16}{*}{$\begin{array}{l}\text { Hasil } \\
\text { Belajar } \\
* \\
\text { Motiva } \\
\text { si }\end{array}$} & B Combin & 329,40 & 2 & 14,322 & 5,337 & ,00 \\
\hline & e ed & 2 & 3 & & & 4 \\
\hline & $\mathrm{t}$ Linearit & 220,92 & 1 & 220,92 & 82,33 & ,00 \\
\hline & w y & 4 & & & & 0 \\
\hline & $\mathrm{e}$ Deviati & 108,47 & 2 & 4,931 & 1,838 & ,16 \\
\hline & e on from & 8 & 2 & & & $\mathbf{0}$ \\
\hline & $\begin{array}{l}\mathrm{n}_{\text {Linearit }} \\
\mathrm{C}_{\mathrm{y}}\end{array}$ & & & & & \\
\hline & $r^{y}$ & & & & & \\
\hline & o & & & & & \\
\hline & $\mathrm{u}$ & & & & & \\
\hline & $\mathrm{p}$ & & & & & \\
\hline & $\mathrm{S}$ & & & & & \\
\hline & Within & 26,833 & 1 & 2,683 & & \\
\hline & Groups & & 0 & & & \\
\hline & Total & 356,23 & 3 & & & \\
\hline & & 5 & 3 & & & \\
\hline
\end{tabular}

Sumber: Data Olahan Peneliti, 2021.

Penelitian ini bertujuan untuk mengetahui pengaruh motivasi terhadap hasil belajar siswa kelas 3 B Tahun Pelajaran 2020/2021 di SDN Pasarkemis 2. Penelitian ini terdiri dari 2 variabel yaitu, variabel motivasi (X) \& variabel hasil belajar (Y). Instrumen yang dipakai untuk mengumpulkan data adalah angket atau kuesioner untuk variabel motivasi, dan untuk hasil belajar dengan survey hasil nilai belajar. Sebelum melakukan analisi untu uji hipotesis penelitian, angket atau kuesioner di uji instrumen terlebih dahulu yaitu uji validitas dan reliabilitas. Hasil uji validitas pada kuesioner motivasi diperoleh 25 butir pernyataan semua valid, yang terdiri dari motivasi positif sebanyak 15 butir dan motivasi negatif sebanyak 10 butir pernyataan. Nilai uji validitas motivasi mulai dari 0,412 sampai 0,762 . Sedangkan hasil belajar dengan data nilai belajar.

Kemudian dilakukannya uji determinasi $\left(\mathrm{R}^{2}\right)$ menggunakan progam SPSS for windows release 24 , dapat diketahui nilai $R$ Square adalah 0,620 , hal ini berarti $62,0 \%$ variasi variabel terikat yaitu hasil belajar bisa dijelaskan dengan variasi variabel bebas yaitu motivasi. Sedangkan sisanya sebanyak 38,0\% variabel dependen hasil belajar dijelaskan dengan variabel lain yang tidak dijelaskan pada penelitian ini. Adapun hasil perhitungan uji parsial (t) bisa diketahui bahwa variabel motivasi memiliki nilai signifikan sebesar $0,000<$ dari tingkat signifikan 0.05 , oleh nilai koefisien beta sebesar 0,788 memiliki arah pengaruh positif, artinya motivasi mempunyai pengaruh positif dan signifikan terhadap hasil belajar, semakin tinggi motivasi bahwa semakin tinggi pula hasil belajar siswa.

Berdasarkan hasil data tersebut, variabel motivasi berpengaruh secara positif dan signifikan terhadap variabel hasil belajar. Sehingga meningkat motivasi, maka semakin tinggi pula hasil belajar siswa. Sehingga sesuai penjelasan yang telah diuraikan, maka hipotesis pertama di penelitian ini diterima, artinya motivasi memiliki pengaruh positif dan signifikan terhadap hasil belajar.

Adanya pemberian motivasi dari orang tua untuk anak dalam pendidikan, maka saat belajar akan senantiasa mengikuti perkembangan dan menemukan jati dirinya. Orang tua harus tetap memberi perhatian penuh supaya anak tidak salah dalam menentukan jati dirinya, ikuti terus memantau gerak-gerik dalam perkembangan dan pertumbuhan anak. Jika ada motivasi maka hasil belajar akan maksimal, sehingga motivasi akan menentukan upaya belajar anak atau siswa.

Pendekatan orang tua dalam komunikasi dan motivasi sangat berpengaruh terhadap pendidikan dalam hasil belajar, karena dengan adanya pendekatan orang tua dan anak dapat meningkatkan semangat belajar para siswa dalam pendidikan. Tujuan dari pendidikan itu salah satunya menjadikan si anak berpikir lebih baik dalam hal untuk menyelesaikan atau memecahkan masalah, dan menyampaikan apa yang ada di pikirannya, tapi kenyataan pada pelaksanaan pembelajaran masih kurang untuk mendorong anak untuk menyampaikan apa yang ada dipikirannya.

\section{PENUTUP}

Simpulan

Berdasarkan hasil analisis pada Bab sebelumnya, maka hasil penelitian tentang pengaruh 
motivasi terhadap hasil belajar siswa Kelas 3 B Tahun Pelajaran 2020/2021 SDN Pasarkemis 2, dapat ditarik simpulan yaitu; Terdapat pengaruh positif dan signifikan motivasi terhadap hasil belajar siswa Kelas 3 B SDN Pasarkemis 2. Arah pengaruh postif artinya semakin tinggi motivasi maka semakin tinggi pula hasil belajar siswa. Besar sumbangan pengaruh sebesar $62,0 \%$ variabel motivasi mempengaruhi hasil belajar siswa, sedangkan sisanya sebesar 38,0\% variabel hasil belajar dipengaruhi variabel lainnya di luar model.

\section{Saran}

Berdasarkan simpulan yang telah didapat dari hasil penelitian ini, bahwa ada beberapa saran yang peneliti berikan yang berkaitan dengan motivasi dan hasil belajar, yaitu sebagai berikut.

\section{Kepada guru}

Guru hendaknya selalu meningkatkan motivasi yang dimiliki oleh masing-masing orang tua maupun murid agar murid dapat mempunyai hasil belajar yang tinggi dan tercapainya tujuan pembelajaran. Dengan cara memberi pembukaan atau awalan pembelajaran secara online dengan kata-kata motivasi, maupun dengan cerita yang dapat memberi motivasi ke siswa maupun otang rua di rumah.

\section{Kepada orang tua}

Orang tua disarankan selalu memberi motivasi, dorongan, arahan atau semangat kepada putra dan putri selama mendampingi proses belajar di rumah selama masa pandemi seperti sekarang ini. Hal ini bisa digunakan melalui cara orang tua meluangkan waktu mendampigi anak belajar di rumah, mengarahkan, menjelaskan materi yang diberikan guru secara daring atau online, perhatian dan semangat yang diberikan orang tua di rumah akan meningkatkan hasil belajar siswa sesuai dengan tujuan pembelajaran sekolah.

\section{Bagi peneliti selanjutnya}

Penelitian ini bisa dikerjakan balik dengan objek penelitian yang tidak selaras, serta penelitian ini bisa dimanfaatkan menjadi bahan rujukan dalam melakukan penelitian yang berkaitan dengan motivasi serta hasil belajar. Peneliti selanjutnya dapat juga mencari variavel lainnya yang diduga juga mempengaruhi hasil belajar siswa seperti pendampingan orang tua, kedisiplinan siswa, kecerdasan (intelektual, emosional, dan spiritual), sarana dan prasarana, dan lain sebagainya. Untuk membuktikan dugaan tersebut perlu dilakukan penelitian selanjutnya.

\section{DAFTAR PUSTAKA}

Andriani, R., \& Rasto, R. (2019). Motivasi belajar sebagai determinan hasil belajar siswa. Jurnal Pendidikan Manajemen Perkantoran, 4(1), 80. https://doi.org/10.17509/jpm.v4i1.14958

Ardiyana, R. D., Akbar, Z., \& Karnadi, K. (2019). Pengaruh Keterlibatan Orang Tua dan Motivasi Intrinsik dengan Kepercayaan Diri Anak Usia Dini. Jurnal Obsesi: Jurnal Pendidikan Anak Usia Dini, 3(2), 494. https://doi.org/10.31004/obsesi.v3i2.253

Cahyani, A., Listiana, I. D., \& Larasati, S. P. D. (2020). Motivasi Belajar Siswa SMA pada Pembelajaran Daring di Masa Pandemi Covid19. IQ (Ilmu Al-Qur'an): Jurnal Pendidikan Islam, 3(01), 123-140. https://doi.org/10.37542/iq.v3i01.57

Daryani, S. (2020). the Influence of Student Learning Motivation and Parents Attention on. Jurnal Ilmu Pendidikan, 15(3), 26-36.

Dwijayani, N. M. (2019). Development of circle learning media to improve student learning outcomes. Journal of Physics: Conference Series, 1321(2), 171-187. https://doi.org/10.1088/17426596/1321/2/022099

Ekonomi, S. P., Ekonomi, F., \& Medan, U. N. (2018). Jurnal Ekonomi Pendidikan Volume 7: Nomor 5 Juni 2018 PENGARUH KOMUNIKASI DAN MOTIVASI ORANGTUA TERHADAP PRESTASI BELAJAR SISWA PADA MATA PELAJARAN EKONOMIKELAS X SMA CINTA BUDAYA MEDAN TAHUN AJARAN2016 / 2017 Zahra * Korespondensi : tengkuzahrafadhilha@yahoo.co.id Jurnal Ekonomi Pendidikan Volume 7 : Nomor 5 Juni 2018

Mayasari, F. (2017). Pengaruh konsentrasi belajar terhadap hasil belajar siswa. Pendidikan Administrasi Perkantoran, 1-11.

Pada, A. (2021). JIKAP PGSD : Jurnal Ilmiah Ilmu Kependidikan Pengaruh Pola Asuh Orangtua Terhadap Hasil Belajar Siswa Kelas IV Sekolah Dasar. JIKAP PGSD: Jurnal Ilmiah Ilmu Kependidikan, 5(2), 375-386. https://ojs.unm.ac.id/JIKAP/article/view/209 12

Pengaruh PMA, PMDN, TK, dan I. (2020). No Title. 2507(February), 1-9.

Ricardo, R., \& Meilani, R. I. (2017). Impak Minat dan Motivasi Belajar Terhadap Hasil Belajar Siswa. Jurnal Pendidikan Manajemen Perkantoran, 2(2), 79. https://doi.org/10.17509/jpm.v2i2.8108

Rumbewas, S. S., Laka, B. M., \& Meokbun Prodi 
Pendidikan Guru Sekolah Dasar STKIPBIAK Jl Bronco Ridge, N. (2018). Peran Orang Tua Dalam Miningkatkan Motivasi Belajar Peserta Didik di Sd Negeri Saribi. Jurnal EduMatSains, 2(2), 201-212.

Saputra, H. D., Ismet, F., \& Andrizal, A. (2018). Pengaruh Motivasi Terhadap Hasil Belajar Siswa SMK. INVOTEK: Jurnal Inovasi Vokasional Dan Teknologi, 18(1), 25-30. https://doi.org/10.24036/invotek.v18i1.168

Saputri, E. (n.d.). Pengaruh motivasi orang tua terhadap hasil belajar siswa pada mata pelajaran ekonomi.

Sugiono (2013). Metode Penelitian Kuantitatif, Kualitatif Dan RnD. Bandung: Alfabeta 